IZA DP No. 9057

Winners and Losers among Skilled Migrants:

The Case of Post-Accession Polish Migrants to the UK

Pawet Kaczmarczyk

Joanna Tyrowicz

May 2015 


\title{
Winners and Losers among Skilled Migrants: The Case of Post-Accession Polish Migrants to the UK
}

\author{
Paweł Kaczmarczyk \\ University of Warsaw \\ and IZA \\ Joanna Tyrowicz \\ University of Warsaw \\ and National Bank of Poland
}

Discussion Paper No. 9057
May 2015

IZA

P.O. Box 7240

53072 Bonn

Germany

Phone: +49-228-3894-0

Fax: +49-228-3894-180

E-mail: iza@iza.org

Any opinions expressed here are those of the author(s) and not those of IZA. Research published in this series may include views on policy, but the institute itself takes no institutional policy positions. The IZA research network is committed to the IZA Guiding Principles of Research Integrity.

The Institute for the Study of Labor (IZA) in Bonn is a local and virtual international research center and a place of communication between science, politics and business. IZA is an independent nonprofit organization supported by Deutsche Post Foundation. The center is associated with the University of Bonn and offers a stimulating research environment through its international network, workshops and conferences, data service, project support, research visits and doctoral program. IZA engages in (i) original and internationally competitive research in all fields of labor economics, (ii) development of policy concepts, and (iii) dissemination of research results and concepts to the interested public.

IZA Discussion Papers often represent preliminary work and are circulated to encourage discussion. Citation of such a paper should account for its provisional character. A revised version may be available directly from the author. 
IZA Discussion Paper No. 9042

May 2015

\section{ABSTRACT}

\section{Winners and Losers among Skilled Migrants: The Case of Post-Accession Polish Migrants to the UK}

We test if migration leads to increased wages. We take the example of Polish migrants to the United Kingdom and focus on the mobility of well educated Poles. We offer insights into absolute and relative change in wages of the migrants, utilizing the data from the UK and Polish labor force surveys. We find that while overall the returns to migration are low, they are negligible or even insignificant for the highly skilled migrants from Poland to the UK. These results hold for both absolute and relative measures.

JEL Classification: J24, J31, J61

Keywords: mobility of the highly educated, return to human capital, relative deprivation, Propensity Score Matching

Corresponding author:

Paweł Kaczmarczyk

Centre of Migration Research

University of Warsaw

ul. Banacha $2 b$

02-097 Warsaw

Poland

E-mail: p.kaczmarczyk@uw.edu.pl 


\section{Introduction}

The UE accession by ten countries from Central and Eastern European marked intensified international mobility from those countries to the UK. Increase in scale was accompanied by a change in the characteristics and destination markets of the new migrants, which is commonly assessed as spectacular social and economic phenomenon. Unless forced by natural disasters or conflicts, according to theoretical frameworks labor mobility is driven by expected wage gains. However, this theory poorly explains why the post-accession CEECs migrants flew to the UK rather than other EU15 countries - wages in the UK were higher than in CEECs on average, but they would also be higher in Sweden or France which too opened their labor markets to CEECs citizens.

While wages may be the key driving factor (neoclassical macro approach to migration), human capital approach claims that - especially skilled - migrants may find it indispensable to seek employment outside home country in order to fully reach the potential, develop further human capital etc. (Sjaastad 1962). This theory of international mobility suggests that migrants tend to choose destination countries instrumental to specific professions they want to pursue rather than the overall wage gap (to maximize returns in the long run).

Both approaches suggest that migrants from CEECs to the UK should observe higher wages and/or higher returns to human capital than they would have achieved without international mobility. It is our objective in this paper to put these predictions into an empirical test. We take the example of Polish migrants as they constitute the largest group of immigrants from CEECs in the UK. Also, UK was the largest receiving EU country in the post-enlargement period. We formulate two research questions. First, we ask if migration of well educated ${ }^{1}$ Poles to the UK lead to an improvement in earned income (in absolute and relative terms). Second, we inquire if migration helps to increase returns to human capital in the case of well educated Poles. We hope to contribute to the literature in two ways. First, we propose a fairly novel way to address the problem of self-selection in analysing economic migration. Second, we provide an empirical assessment of the income position of Polish migrants in the UK relative to the stayers in Poland and to the other participants of the British labor market.

We utilize detailed data on Polish migrants available in the UK Labor Force Survey. The counterfactual distribution of wages is constructed in two ways. First, we utilize Polish Labor Force Survey from the analogous periods and employ propensity score matching to reduce the self-selection bias. We analyse both absolute and relative incomes, using also a variety of relative deprivation measures. Second, we employ parametric methods to evaluate the returns to human capital. We analyse well educated Polish migrants against the natives and other migrant groups to assess the wage premium for a given group.

We find that overall the returns to migration are low, they are negligible or even insignificant for the highly skilled migrants from Poland to the UK. These results are true for both absolute and relative measures. Notwithstanding, educated Poles are relatively well off when compared to uneducated migrants from the A8 countries to the UK. These results suggest that the importance of both absolute as well as relative wage argument does not seem to be the main

${ }_{1}$ We will use terms: well educated, well skilled and high skilled interchangeably when referring to people with tertiary education. Note, however, that there is an extensive scientific debate on the very meaning of skills and education in studies on migration decision making (see e.g. Ackers and Gill 2008). 
driver of these particular migration flows. Decision to migrate may be conditional also on the opportunities posed by the relevant labor markets, which are not quantifiable if we go beyond such indicators as unemployment. Also social and cultural aspects may play an important role. Thus, decisions to migrate are far more complex than foreseen by neoclassical economic migration theories.

The paper is structured as follows. The next section - motivation part - attempts to provide necessary background information for the analysis presented further: brief description of the main trends and characteristics of the post-enlargement from Poland and theoretical and literature survey (including both literature on causes of migration as well as on immigrants' position on the receiving labor market). Third section discusses the empirical strategy applied and data used. In the fourth section we present the results. Policy recommendations emerging from this study are discussed in the concluding section.

\section{Background and motivation}

Poland is a an emigration country with over century long tradition of outward mobility, including transcontinental migration to the United States, massive labor migration to the Western European countries and several flows of politically motivated movers (Jaźwińska and Okólski 2001; Kaczmarczyk 2005; Stola 2010). However, even considering previous massive waves of migration, accession into the European Union was a turning point regarding trends in migration from Poland as well as from other accession countries. From the perspective of the EU15 the 2004 enlargement was unprecedented for a few reasons, including much higher differences in income/wage levels that in case of previous accession rounds and the fact that set of accessing countries complied transition economies. Those factors explain relatively high expectations concerning future migration flows from the A8 countries (Kaczmarczyk 2013).

In the case of the UK, the relatively higher propensity to migrate from Poland was combined with a relatively high absorption capacity in the destination labor market. In addition, structural problems in sending labor market further fueled the migration flows, making it fairly unprecedented (see Kaczmarczyk 20011; Grabowska and Okolski 2009; Okólski and Salt 2014).

\section{Polish post-enlargement migration to the UK}

The number of permanent residents of Poland staying temporarily abroad - referred to as temporary migrants - increased from around 1 million in 2004 to over 2.3 million in 2007 (6.6 percent of the total population). Since then the stock of migrants has decreased slightly (mostly due to the economic crisis in the destination countries) but still remains as high as 2.2 million people in the end of 2013 (GUS 2014).

In addition to the scale, also the structural features of the migration flows were phenomenal. First, there was an important shift in destination countries observed. Germany - the most important target country in the pre-accession period - lost its top position (hosted less than 25 percent of Polish migrants in 2008) and at the same time both Anglosaxon countries experienced a spectacular inflow from Poland: the stock of migrants staying in the UK rose from 
24,000 in 2002 to almost 700,000 in $2008^{2}$ (GUS 2014), for an analysis of these flows see Kaczmarczyk 2011; Kaczmarczyk and Okólski 2008; Okólski and Salt 2014.

Second, one of the most specific features of recent migration from Poland is the predominance of orientation on work. An overwhelming majority of Polish migrants (over 90 percent) take up employment while staying abroad (Kaczmarczyk 2011).

Third, post-accession migration flows from Poland are highly selective in terms of structural characteristics. Recent Polish migrants are significantly younger than it was noted in case of previous cohorts and much better educated than in previous decades with almost 20 percent of persons holding a university degree, see: Grabowska and Okólski 2009; Kaczmarczyk and Okólski 2008; Kaczmarczyk 2011. This feature raises the question of impacts of migration on the human capital formation (brain drain / gain debate) but also on the position of immigrants in the host country and returns to education.

\section{Theoretical foundations and empirical survey}

While looking at the importance of returns to education in migration decision making this paper refers to two important strands in migration and labor market literature. The first one assesses absolute and relative wage differentials as possible drivers of migration. The second one explores the labor market position of immigrants on the receiving labor market ant its determinants (including returns to education).

\subsection{Wage differentials and propensity to migrate}

Wage differentials are traditionally considered as (one of) the most important factors responsible for both internal and international mobility. Understanding and explanation of this relationship however strongly depends on a set of assumptions taken and varies across scientific approaches. Within the Hecksher-Ohlin-Samuelson framework (Mundel 1957; Samuelson 1948) migration plays instrumental role only - mobile agents are assumed to respond to wage differentials and migration itself leads to equalization of wages (neoclassical macro approach). Similalry, Harris and Todaro (1970) view migration as a function of wage differentials (but assessed rather in expected terms, i.e. including level of unemployment as a proxy of employment probability). Wage differentials are also integral part of all microeconomic approaches to migration where migration decision is clearly driven by net present value of (expected) wage or income differentials (Fischer, Martin and Straubhaar 1997). Importantly, the neoclassical microeconomic approach to migration assumes that would-be migrants compare returns to their skills/education available to obtain in target countries under consideration and make the migration decision accordingly. Thus migration is an investment decision aimed to increase productivity of one's labor (human capital approach - Sjaastad 1962). Similarly, wage differentials and differences in return to human capital are expected to affect migration selectivity patterns (Borjas 1987).

Those approaches considering differences in absolute wages only (on micro or macro level) as a decisive factor influencing migration have been seriously challenged by scholars arguing that relative income measures are as important in migration decision making as the absolute ones. Relative deprivation approach proposed by Stark (1984), Stark and Bloom (1985) and

\footnotetext{
${ }^{2}$ In case of Ireland the increase was even higher - from 2,000 to 200,000
} 
developed further by Stark and Yitzhaki (1988) and Stark and Wang (2000) is based on a general observation saying that one's comparison of his/her income with the incomes of other members of particular reference group (to be determined) may result in a feeling of relative deprivation and thus become source of negative utility. Accordingly, Stark and others suggest to include the relative deprivation as one of important "push factors" in migration analysis. The general prediction is that, holding all other variables constant, a non satisfactory or deteriorating relative position within a reference group will result in migration decision and that expected outcome of this decision is change in one's relative income position (decrease in relative deprivation).

From the theoretical literature on causes of migration it follows that, generally, both absolute as well as relative wages/incomes are important explanatory factors for migration decision. Absolute wage differentials are commonly included in most of the empirical models of migration and it was proven that they act as significant pro-migratory factors (Hatton and Williamson 2002; Carletto et al. 2004; Quinn 2006). The number of empirical studies dealing with the relative deprivation approach is far more limited and results in this matter are hardly unambiguous. Stark and Taylor (1989) provide empirical evidence that those Mexican households who were classified as being relative deprived (in income terms, village treated as reference group) had higher propensity to move to the United States. Stark and Taylor (1991a, 1991b) include relative deprivation variables (based on income only) into migration models but suggest to treat them as an additional factor (i.e. not replacement for absolute wage differentials) responsible for migration dynamics. Based on the Mexican data they conclude that relative deprivation had significant and positive impact on migration to the US but not on patterns of internal mobility (when controlled for absolute income). Queen (2006) utilizes the cross-sectional data taken from the Mexican Migration Project and constructs several measures of relative deprivation (income deprivation, land deprivation and housing size deprivation). He argues that relative deprivation impacted positively internal migration decision but not international migration from Mexico. Additionally, he suggests to refer to variables based rather on wealth and not current income. Won (2012) provides some support for the relative deprivation hypothesis in case of migration decisions of Vietnamese (2004-2006) but interestingly it is significant in case of long-term migration only.

With reference to the Polish migration absolute wage differentials are not very useful in explaining the scale and structure of migration (Kaczmarczyk 2005; Strzelecki and Wyszynski 2011). In both cases other labor market related variables - primarily unemployment rates - are considered as more explicit explanatory factors. Based on data collected in several Polish regions in late 1990s Kaczmarczyk (2005) proves adequacy of the relative deprivation approach for modeling of migration decisions on the household level.

\subsection{Labor market position of immigrants at destination and its determinants}

One of the aims of this paper is to test what are returns to skills of Polish post-2004 migrants to the UK. Thus the second strand of literature we review here analyzes how immigrants fare on the receiving labor market in terms of their wage position and specifically whether they human capital is being paid accordingly.

Considering the very fact that immigrants are relatively more often over-educated for jobs they do perform and earn less than natives (OECD 2007; UNDP 2009) there is a vital theoretical and 
empirical debate on that issue. Chiswick (1978) claims that immigrants are expected to earn less than natives as long as they lack location specific human capital (predominantly related to or resulting from language skills). Moreover, immigrants from culturally and socially similar countries are assumed to have lower wages disadvantages then immigrants from culturally distant countries. ${ }^{3}$ Borjas (1987) proposes an idea of the immigrant market to explain the selfselection patterns and to discuss the assumed wage differentials between natives and newcomers. In series of articles (Borjas 1985, 1987, 1994) he points to structural differences between subsequent cohorts of the US immigrants as responsible for differences in labor market performance (cohort effect). Differences in the overall human capital in a given (sending) country and features of migration policies regarding highly and low skilled are identified as the main factors shaping the 'placement' of migrants at destination by Özden (2006). Recently growing emphasis is being put on the imperfect portability of human capital across countries and educational systems. Friedberg (2000) claims that position of immigrants on a given labor market can be a result of not only their levels of education, experience or training but rather (or as well as) how these characteristics are valued at destination. This observation reflects the proposition by Borjas (1987) and is strengthen by Csedo (2008) who suggests to refer to the transferability of skills 4 .

There is a broad range of papers assessing the determinants of immigrants' wages in a an empirical way both in the North American (Portes and Bach 1980; Rivera-Batiz 1990; McDonald and Worswick 1998; Borjas 1987, 1994; Chiswick and Miller 2002) as well as in the European context (Shields and Wheatley Price 1998; Hansen and Lofstrom 2003). Most of the studies conclude that empirically observed differences in wages do exist and they can be explained by such factors as level of education (in most studies) and type of the educational system (particularly: proximity of the educational systems - Freedberg 2000), job tenure (in most studies but to limited extent only), cohort effect (Borjas 1985; Schafsmaa and Sweetman 2001) and business cycle effect (Barrett and McCarthy 2007; Dustmann, Glitz and Vogel 2010), type of migration (Dustmann 2000; Clark and Drinkwater 2008; Adda et al. 2014) but still there exists a residual gap. This gap can be explained in terms of discriminatory practices (Shields and Wheatley Price 1998; Blackaby et al. 2002; Friedberg 2000) or unobservable characteristics, including language proficiency. The latter factor is commonly presented as one of the most important variables hypothetically shapint the labor market performance of immigrants. In pioneer studies Kossoudji (1988) and Rivera-Batiz (1990) claim that the command of English (reading proficiency in case of Rivera-Batiz paper) is a major factor responsible for wage level of immigrants and that language deficiencies are costly. Shields and Wheatley-Price (1998) suggest that large part of the wage gap between natives and immigrants can be explained by differences in return to human capital depending on the place where it was acquired in (e.g. in the UK or elsewhere). Chiswick and Miller (2002) find that in case of the US immigrants (in late 1980s) English language fluency is among the most important explanatory factors when assessing the determinants of earnings (but also that there is a strong complementarity between language skills and other forms of human capital). Dustmann and Fabbri (2003) prove language proficiency to have a significant and positive impact on the labor market performance, including level of wages. Shields and Wheatley Price (2001) obtain similar results with respect

\footnotetext{
${ }^{3}$ Part of those outcomes is questioned by Bell (1997) who in case of the UK labour market suggests that low level of the location specific capital can be compensated by other factors responsible for relatively higher productivity of immigrants (but this was true only in case of selected immigrants' categories).

${ }^{4}$ Based on a qualitative and qualitative study Csedo (2008) concludes that language skills are absolutely critical among the young professionals and highly skilled Hungarian and Polish immigrants in London. She introduces the term transferability of skills to emphasize the importance of language proficiency in terms of obtaining position on the labour market relevant to ones skills.
} 
to the occupational success on the British labor market. Notwithstanding, outcomes of most of quoted studies depend heavily on the quality of data and particularly self-assessment of the language skills (see also Chiswick and Miller 1995).

Along with the massive migration flows from the A8 countries the number of empirical studies assessing patterns of migration and position of immigrant workers in the UK (and Ireland) grew significantly but relatively few of them address directly the issue of returns to education 5 . Drinkwater, Eade and Garapich (2009) are among the first authors who assess the labor market performance of A8 immigrants in the UK. Based on the UK LFS data they conclude that despite having relatively high levels of education (in fact higher than in case of natives) they managed to find employment mostly in low-paid sectors and generally far below their skills (and earn much less than immigrants from previous cohorts). Additionally, they point to low returns to education observable particularly in case of Polish migrants (but without controlling for selection bias). In more recent paper Clark and Drinkwater (2008) compare the labor market outcomes of A8 immigrants in the UK with native-born. They note significant differences in labor market outcomes between ethnic and migrant groups with a noticeable case of the A8 recent immigrants representing both high levels of skills and very high participation ratios. At the same time however A8 migrants' earnings are very low considering their characteristics. According to authors this wage penalty might reflect the host-country-specific skills whereas A8 immigrants were suffering from serious mismatch in terms of their skills and earnings. Clark and Drinkwater (2009) extend this analysis by including the issue of immigration impacts in case of different ethnic and minority groups. They also note extremely favorable set of sociodemographic characteristics of the new immigrants which was not matched by the labor market position. Notwithstanding there is a discrepancy between educational attainments and wage levels clearly visible and authors attempt to explain it in terms of language skills and migration strategies (temporary migration). In both studies the importance of language skills is emphasized (but not assessed due to data deficiencies).

Barrett (2009) analyzes the position of Ireland as one of the most important receiving countries in the post-accession period. He concludes that the A8 immigrants have very high participation rates and education rates comparable to native workforce. Nevertheless, their earnings are significantly lower than in case of natives and the same holds true in case of their occupational structure (overeducation). Barrett and McCarthy (2007) show that these differences do not disappear when controlling for education and years of work experience. They suggest also that the command of English may be one of the crucial factor to explain the variance in wages across Irish labor market. Dustmann, Frattini and Halls (2010) in a study based on the UK LFS data find that A8 immigrants in the UK are much better educated than natives (32 percent of men and 40 percent of women were classified as highly educated), do have higher participation ratios (95 percent for men and 80 percent for women as corresponding to 83 and 75 for natives respectively), and higher employment rates ( 90 percent for men and 74 percent for women as compared to 78 and 71 percent for natives). Despite all these features they are able to achieve level of wages considerably lower than in case of natives - for A8 male immigrants the average hourly wage was as high as $6.81 \mathrm{GBP}$ (median - 6.07 GBP) as compared to $11.91 \mathrm{GBP}$ in case of

\footnotetext{
5 There is a broad range of studies assessing the impacts of migration on the receiving labour market but not necessarily looking at the immigrants themselves (e.g. Barrett, FitzGerald and Nolan (2002) examine the impacts of immigration to Ireland in mid-1990s on earnings inequality and returns to education but in the perspective of the whole labour market; Dustmann, Frattini and Preston (2008) find that the effect of supply shock on the native labour force depend on the position in income distribution but also that immigrants downgrade considerable in country of destination; Card, Dustmann and Preston (2011) look at changes in composition of the receiving population and compositional amenities derived by natives from neighborhoods or workplaces).
} 
natives (median - 9.76 GBP) and additionally, the gap is larger at the top of the wage distribution suggesting considerable brain waste effect 6 .

To sum up, empirical research on recent Polish migration documents significant positive selection with regard to human capital. Nonetheless this selectivity pattern is accompanied by severe over-education and labor market mismatches. None of the above quoted studies considers returns to education both in the sending and receiving country. Thus the main contribution into the literature of our article is the comparison of labor market performance of recent Polish well educated migrants in the UK and their (statistical) counterparts in Poland and discussion of underlying factors.

\section{Methods and data}

As discussed in the motivation section, there is extensive evidence - both quantitative and qualitative - that subsequent to arrival in a destination country some of the highly educated migrants from the A8 countries actually are able to acquire jobs concordant with their educational attainments, whereas some are not. On top of this, although full achievement could be unattainable on average, it may actually hold that highly educated migrants are able to earn returns to their human capital even occupying positions that do not require a degree. Given this evidence, our primary objective is to test which of these effects is quantitatively dominant, i.e. whether migrants from the A8 countries are able to achieve higher wages and/or higher returns to human capital than their not mobile counterparts.

Followingly, this study attempts to answer two basic questions. First, we inquire if migration of the well educated Poles migrants to the UK leads to an improvement in terms of their earned income (in absolute and relative measures). Second, we ask if migration to the UK increases returns to human capital in case of this particular migrant group. This section describes in detail the empirical strategy to address these questions, data characteristics as well as some stylized facts that emerge from data prior to a statistical analysis. The original identification comprises of two strategies. In the first one we employ propensity score matching (PSM) to compare the wages of Poles who migrated to the UK to those who remained in Poland. We will thus match Poles in the British LFS to Poles in the Polish LFS. In the second one we try to estimate returns to human capital, conditional on potential frictions in the hosting labor market. We discuss these two strategies below. In the final subsection we carefully describe the available data.

\section{Propensity score matching to identify the causal effect of migration on the earnings of migrants}

Propensity score matching is typically applied to estimate causal treatment effects, e.g. the effectiveness of labor market policies, pharmaceutical research, profitability of particular marketing solutions or the effect of institutions on economic development ${ }^{7}$. The critical element in propensity score matching lies in the conditional independence assumption construct. In other words, for the reliability of the results it is important that the selection is solely based on observed characteristics and that all variables that influence migration behavior and potential 2008.

${ }^{6}$ They note however that the wage growth in case of immigrants is much higher than in case of natives over the period 2004-

${ }^{7}$ Caliendo and Kopeinig (2008) discuss in detail recent development as well as guide through the process of adequate construct of this approach. 
earnings are simultaneously observed. In practice it implies that there should be no other sources of systematic (i) selection and (ii) outcome.

Migrations are both highly selective and likely to be driven by unobservable characteristics. Whereas the former phenomenon may be accounted for statistically, the latter requires instrumenting or some other idenfitication strategy to eliminate the endogeneity bias. Given these two confounding components, we employ PSM as a device to reweight the observations on observable characteristics, thus accounting for selectivity. We do not claim that this identification has causal interpretation in terms of expectations of migrants and stayers prior to making the decision about location of work. What we do claim, though, that given these decisions and after satisfying the balancing properties, PMS yields a reliable comparison of wages between the stayers and the migrants.

With propensity score matching, the quality of estimation depends much on the data availability. In the case of this study, the pool for matching (the size of the control sample in the relation to the size of the analysed sample) is relatively large, so there is no need for k-nearest neighbors matching, nor for sampling with or without replacement. We thus apply kernel estimates of propensity scores with the nearest neighbour matching, following Heckman et al. (1998). Additional robustness is provided via local linear regression matching. Alternatively, we could have used the over-sampling technique. However, the choice of the over sampling magnitude is always arbitrary, while 40-fold over sampling (as feasible in our sample) does not differ from the kernel approach in terms of statistical quality.

The choice of matching and comparison variables is still in question, though. We discuss this in detail below.

\section{Matching variables choice under PSM}

Unequivocally demographic variables like age, gender, as well as an educational attainment and marital status should serve to match migrants to stayers. Occupation and industry indicators, though, are much more doubtful, since migrants frequently undertake the so-called secondary jobs (Piore 1980; Borjas 1987, 1994). This implies they may be willing to (or having to - due to structural conditions on the host labor market) work in occupations and industries different from the ones they would have held if remained in their home country. Having this in mind we decided not to match Polish migrants in the UK to the stayers on occupation or industry.

Migration concerns predominantly younger people, which implies that job tenures may actually may be an important determinant of compensations. The datasets out our disposal allow us to account for that phenomenon. Both British and Polish LFS dispose of information about general tenure as well as tenure with the current employer and we use these variables for matching.

This choice is quite important from the interpretational perspective. First, if we choose not to match on occupation/industry, we implicitly assume that people may be actually willing to hold whatever jobs, as long as they pay a satisfying wage8. This is not necessarily the case for all

\footnotetext{
8 This approach would be particularly well taken in case of temporary migrants who often treat their stay abroad in an instrumental way only, i.e as a means to improve their position in pecuniary terms and not to change their social status.
} 
migrants. It is not likely that one spends 5 years to study architecture in order to be a manager in a local store of a major clothing brand. On the other hand, when choosing Belorussian linguistics one is rarely expecting to work in this profession. Similarly, a relatively large share of Polish graduates completed BA and MA programmes within broadly defined social sciences, which quite often are not associated with one specific profession. Finally, stayers are more likely to hold to their degrees than migrants, especially when starting the career. This stems from the fact that often a degree is the major credential they may demonstrate to the prospective employer.

Given these diverse motivations and career paths, one is prompted to expect that while some graduates would be strongly inclined to eventually work within the field of previous studies, others may be willing to (or having to) disregard previous educational choices given the opportunity to work in a different field. This diversity is reflected in the choice not to use industry and occupation in the matching algorithm.

Summarising migrants are matched to stayers based on gender, age (in years), education (in years), marital status and tenure. To make sure that the matching is adequate, we include additionally interactions of all variables. These interactions were formed based on categorical variables generated from the continuous variables. Matching on interactions facilitates fulfilling the notion of a "statistical twin" even under kernel and local linear regression algorithms. Although the set of variables is limited in this study, it could not be extended for the reasons of data availability. However, we believe that relying on demographics (gender and age) as well as education and individual incentives (marital status) may be sufficient for the stability of propensity score matching approach. We verify this approach empirically by the use of t-tests, as suggested by Rosenbaum and Rubin (1983). The so called balancing properties before and after matching are discussed in the results section.

\section{Comparison variables choice under PSM}

The comparison variables should unequivocally include compensation, but there are clearly issues to be specified as to how are wages compared across Polish migrants to the UK and stayers. First issue concerns the control for the purchasing power. Clearly, pure exchange rate conversion overlooks the fact that living costs are much higher in the UK than in Poland. Notwithstanding, forceful evidence has demonstrated that migrants are often able to substantially cut the consumables expenditure as well as lower the costs of accommodation, for instance by sharing rooms/apartments (Jazwinska and Okolski 2001; Kaczmarczyk 2005; Drinkwater, Eade and Garapich 2009). Thus, while without the control for purchasing power the relative earnings in the UK are overstated, including it may actually undermine the validity of the results as well. We decided to use raw exchange rate conversion without the PPP correction.

Second, absolute wages correspond to a narrowly defined concept of the rewarding value of the compensations. More specifically, there is both theory and empirical evidence that it is not the monetary value but the sense of accomplishment/deprivation that drive the satisfaction from the money earned as clearly suggested in the motivation section (Stark and Bloom 1985; Stark and Taylor 1991b). To account for these effects we included as comparison measure the percentile of distribution in the earning country (Poland for stayers and the UK for migrants). 
The percentile, however, does not account for the fact that people may actually compare themselves not to the whole population but to a much more narrowly defined reference group (Stark and Yithzkaki 1988; Stark and Wang 2000). To address this concern we compute one additional measure, i.e. a ratio between individuals'compensation and mean/median wage in a reference group. There are two definitions of a reference group. In the first one, we account for occupation, education, gender, type of employer and whether one is a full time or a part time worker. In the second definition we also include the nationality, which is irrelevant for the stayers, but has proven to be extremely relevant for the migrants to the UK.

\section{Estimating returns to human capital of migrants}

Since there can be important unobservable determinants undermining the validity of comparing migrants to non-migrants, we designed also an alternative identification strategy which addresses the second research question as specified above, i.e. are Polish well educated migrants able to achieve comparable returns to human capital abroad than other groups (migrants or natives alike)? This strategy consists of estimating a standard Mincerian regression with additional controls for country of origin and level of education in a following form:

$$
\begin{aligned}
\ln (\text { wage })=f(\text { age, gender }, \text { education, fultime job, } \text { public sector }, \text { tenure }) & \\
& +\gamma(\text { occupation, } \text { industry })+\lambda_{1} \text { nationality } \times H E+\lambda_{2}(P L) \times H E+\epsilon
\end{aligned}
$$

where HE refers to higher education, PL to Polish nationality. Estimates of $\lambda$ 's can be interpreted in terms of "special treatment" of human capital embodied in immigrants (and immigrants from Poland particularly). It may be considered an additional reward or penalty to education obtained outside UK. Theoretically, once we account for occupation and industry and control for other socio-demographics there should be no economic reasons for $\lambda_{1}$ nor $\lambda_{2}$ to be statistically different from zero.

Importantly, we do not subscribe to the view that such interactions may capture positive or negative "discrimination" of migrants. In fact, the reasons for which returns to education may differ across countries of origin may result from both demand and supply side. For example, insufficient command of English typically implies inability to present one's skills fully, thus prohibiting obtaining the job adequate to one's education (see motivation section) ${ }^{9}$. Lack of experience in job search will yield the same result, regardless of one's formal academic achievements.

The specification does not comprise Heckman correction. The rationale for such choice stems from the fact that vast majority of migrants work, because this is their major objective subsequent migration. . Thus, Heckman correction would mostly comprise the natives in the UK. In the case of the UK this choice it does not seem to matter, since even if biased - the coefficients on interaction between the education and the country of origin are actually only estimated in relative terms. On the other hand, excessive wage expectations may lead to both higher unemployment in the sending country and simultaneously higher propensity to emigrate. While

\footnotetext{
${ }^{9}$ Unfortunately, due to data deficiencies we are not able to include language variables in the estimation.
} 
Heckman correction could be particularly desirable in this situation, this paper does not estimate wage equation in the sending country.

\section{Data and stylized facts}

Data for this paper come from two labor force surveys: that for the sending country (Poland) and that for a receiving country (the United Kingdom). As of 2004 a growing number of Poles may be identified in the UK LFS, whereas due to the standardization of this type of surveys makes it feasible to combine such analyses. The number of Poles in the UK LFS as well as the intensity of the migration processes set the lower boundary on the time frame to comprise survey from 2007. For the reasons of data availability, the period covered ends in 2010.

Alltoghether, the data comprise observation on 1989 Poles in the UK LFS from about 220000 data on socio-economic indicators and compensations ${ }^{10}$, i.e. about 1 per cent of the surveyees. In order to be selected for participation in UK LFS, one has be resident in the UK for at least 12 months, which eliminates from the sample those migrants, who either came once for a short stay or come regularly but for short contracts.

The matching population from the Polish LFS comprises about 80000 observations on socioeconomic indicators and compensations. The original sample comprises about 400000 observations, but the sample size is considerably reduced when out-of-the-labor-force observations and missing wages are eliminated. Also, Polish LFS does not comprise data on compensations earned by the self-employed so in both of the surveys this group of workers was not analysed.

The sample sizes imply that the comparison group in the UK is about 100 times bigger, whereas the comparison group in Poland is about 40 times bigger. Thus, it seems that the structural mismatch may be reliably eliminated. Detailed summary statistics as well as sample sizes are displayed in Table 1.

${ }^{10}$ Wages are only available in the $2^{\text {nd }}$ quarter of each year, which narrows a sample of about $1 \mathrm{mln}$ observations to about 200000. 
Table 1. Descriptive statistics

\begin{tabular}{lrrrrr}
\hline \hline Variable & Mean & St. Dev & Min & Max & N \\
\hline & \multicolumn{2}{c}{ Poles in PL } & & & \\
\hline Sex (females=1) & 0.466 & 0.499 & 0 & 1 & 83492 \\
Age & 38.979 & 11.532 & 16 & 88 & 83238 \\
Primary education & 0.265 & 0.441 & 0 & 1 & 83238 \\
Secondary education & 0.397 & 0.489 & 0 & 1 & 83238 \\
Tertiary education & 0.338 & 0.473 & 0 & 1 & 83238 \\
Hourly wage (in PLN) & 35.798 & 25.298 & 0 & 625 & 38960 \\
\hline & UK - total sample & & & \\
Sex (females=1) & 0.481 & 0.499 & 0 & 1 & 839665 \\
Age & 41.536 & 13.262 & 17 & 72 & 839665 \\
Primary education & 0.227 & 0.419 & 0 & 1 & 805018 \\
Secondary education & 0.645 & 0.478 & 0 & 1 & 805018 \\
Tertiary education & 0.127 & 0.332 & 0 & 1 & 805018 \\
Hourly wage (in GBP) & 11.587 & 12.737 & 0.18 & 3086.537 & 209307 \\
\hline & UK & Polish immigrants & & & \\
Sex (females=1) & 0.453 & 0.498 & 0 & 1 & 8822 \\
Age & 30.751 & 8.483 & 17 & 72 & 8822 \\
Primary education & 0.104 & 0.305 & 0 & 1 & 8568 \\
Secondary education & 0.577 & 0.494 & 0 & 1 & 8568 \\
Tertiary education & 0.319 & 0.466 & 0 & 1 & 8568 \\
Hourly wage (in GBP) & 7.115 & 4.253 & 0.131 & 124.218 & 2203 \\
\hline \hline
\end{tabular}

Source: Own elaboration based on the UK LFS and Polish LFS data.

We compare the natives in the UK LFS, the Poles in the UK LFS and Poles in the Polish LFS with reference to three major dimensions. First, we look at the educational structures in order to show that there is a clear positive selection of migrants with respect to education (and also that Polish migrants in the UK are significantly better endowed with human capital than native population). Second, we compare the occupational structure, reducing the ISCO rating to highly skilled, skilled and low skilled occupations ${ }^{11}$. We show that both A8 immigrants and Polish immigrants in the UK are overrepresented in low skilled professions. Finally, we also compare the original distributions - i.e. before any estimations - across the analysed sub populations

\section{Educational attainments}

Table 2 presents the educational structures of persons participating in the British and Polish labor market (adults only). In case of the British labor market all of the immigrant groups are better educated than natives (this refers particularly to tertiary education). The same holds true for A8 immigrants and Polish citizens staying in the UK (almost 32 percent of persons with tertiary education as compared to 21 percent in case of natives).

Table 2. Educational attainments in the British and Polish labor market

\begin{tabular}{|l||ccccccccc|}
\hline \hline $\begin{array}{l}\text { Level of } \\
\text { education }\end{array}$ & Natives & $\begin{array}{c}\text { BU14+EEA } \\
\text { migrants }\end{array}$ & $\begin{array}{c}\text { A8 } \\
\text { migrants }\end{array}$ & $\begin{array}{c}\text { Polish } \\
\text { migrants }\end{array}$ & $\begin{array}{c}\text { African } \\
\text { migrants }\end{array}$ & $\begin{array}{c}\text { American } \\
\text { migrants }\end{array}$ & $\begin{array}{c}\text { Asian } \\
\text { migrants }\end{array}$ & $\begin{array}{c}\text { Other } \\
\text { migrants }\end{array}$ & $\begin{array}{c}\text { Natives } \\
\text { market }\end{array}$ \\
\hline Primary & 13.0 & 10.6 & 8.8 & 10.4 & 5.1 & 9.2 & 7.6 & 13.6 & 36.5 \\
Secondary & 65.8 & 44.9 & 60.3 & 57.7 & 52.0 & 54.2 & 39.1 & 40.9 \\
Tertiary & 21.2 & 44.5 & 31.0 & 31.9 & 42.9 & 36.6 & 53.3 & 45.4 & 25.8 \\
\hline$N$ & 749,678 & 13,835 & 12,410 & 8,568 & 6,878 & 2,239 & 11,728 & 1,085 & 74,670 \\
\hline \hline
\end{tabular}

Source: Own elaboration based on the UK LFS and Polish LFS data.

11 Managers and professionals were coded as high skilled occupations, associate professionals and technical staff as skilled ones, administrative staff ans skilled tradesmen as low skilled ones and manual occupations in industry and services as basic ones. 
Moreover, there is a clear selection pattern visible when comparing Polish migrants in the UK with their counterparts in Poland (precisely: on the Polish labor market). In case of mobile Poles less skilled persons are underrepresented and well educated are overrepresented. This picture is clearly consistent with empirical studies discussed in the motivation section.

\section{Occupational structure}

Table 3 documents the occupational structure of workers on the Polish labor market (Poles) and the British one (natives and selected immigrant groups). Clearly, in case of the British labor market natives tend to concentrate in the upper part of the occupational ladder while occupations of immigrants are skewed towards the lower end of the distribution (except for EU14 and EEA immigrants).

Table 3. Occupational structure on the British and Polish labor market

\begin{tabular}{|c|c|c|c|c|c|c|c|c|c|}
\hline \multirow[t]{2}{*}{ Occupation } & \multicolumn{8}{|c|}{ British labor market } & \multirow{2}{*}{$\begin{array}{c}\text { Polish labor } \\
\text { market } \\
\text { Natives }\end{array}$} \\
\hline & Natives & $\begin{array}{c}\text { EU14+EEA } \\
\text { migrants }\end{array}$ & $\begin{array}{c}\text { A8 } \\
\text { migrants }\end{array}$ & $\begin{array}{l}\text { Polish } \\
\text { migrants }\end{array}$ & $\begin{array}{l}\text { African } \\
\text { migrants }\end{array}$ & $\begin{array}{c}\text { American } \\
\text { migrants }\end{array}$ & $\begin{array}{l}\text { Asian } \\
\text { migrants }\end{array}$ & $\begin{array}{c}\text { Other } \\
\text { migrants }\end{array}$ & \\
\hline High skilled & 28.9 & 39.0 & 7.9 & 7.1 & 25.6 & 22.4 & 27.6 & 24.3 & 21.0 \\
\hline Skilled & 14.4 & 16.5 & 4.4 & 3.7 & 17.2 & 13.0 & 14.1 & 17.3 & 10.7 \\
\hline Low skilled & 22.8 & 15.1 & 20.2 & 20.9 & 12.0 & 15.5 & 13.4 & 16.2 & 18.2 \\
\hline Basic & 33.8 & 29.5 & 67.5 & 68.2 & 45.1 & 49.1 & 45.0 & 42.2 & 50.1 \\
\hline$N$ & 779,540 & 14,240 & 12,755 & 1,119 & 7,421 & 2,230 & 12,589 & 1,139 & 100,749 \\
\hline
\end{tabular}

Source: UK LFS and Polish LFS data, 2nd quarters of 2007-2010.

Unequal distribution is particularly well visible when we compare native workers with immigrants originating from A8 countries and Poland. In both cases share of those employed in low skilled or basic occupations exceeds 85 percent (89 percent in case of Polish migrants). This evidence is striking when we refer to previous table showing the educational attainments of A8 migrants. Comparison to the structure of employment on the Polish labor market reveals that Polish migrants in the UK and not seriously overeducated but also for part of them migration to the UK equals degradation in occupational terms.

\section{Distributions of wages}

While the bottom of the wage distribution seems to dominate in Poland among stayers, it is expectedly the top of the distribution that dominates in the UK (Figure 1, right panel) ${ }^{12}$. However, wages of Poles in Poland (stayers) and in the UK (movers) are not significantly different in terms of distribution (important in the context of common support).

\footnotetext{
${ }^{12}$ Both wage distributions were converted to PLN for comparison purposes.
} 
Figure 1. Wage distribution: natives in the UK versus Polish migrants in the UK (left panel) and natives in Poland versus Polish migrants in the UK (right panel)

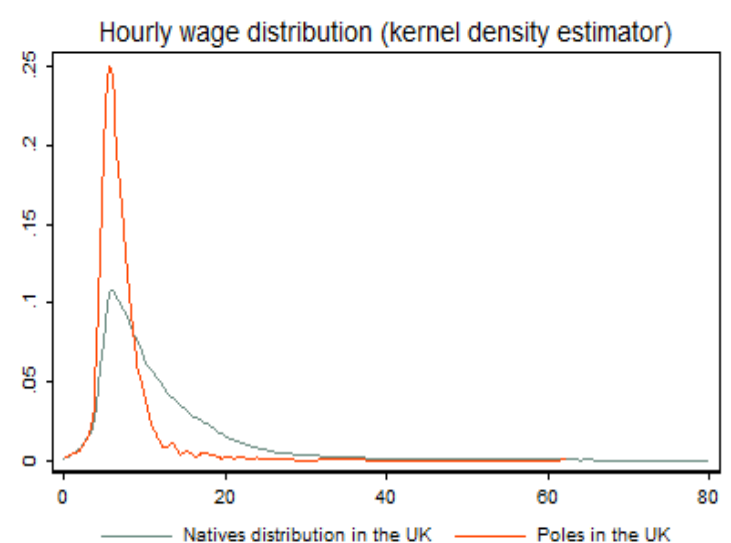

Hourly wages in Poland (kernel density estimator)

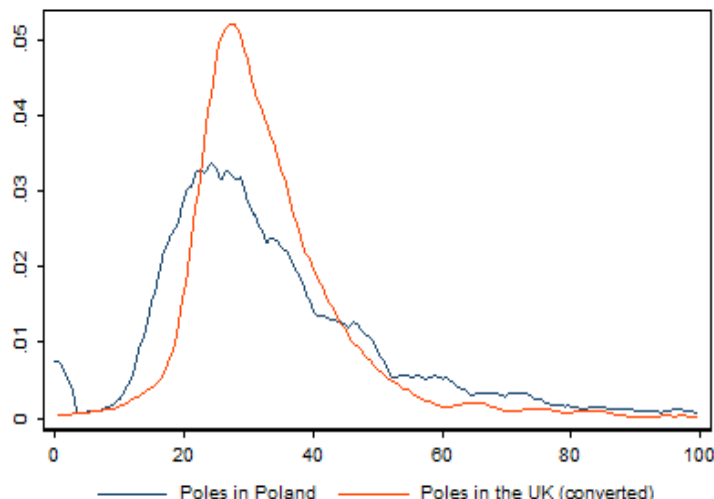

Source: UK LFS and Polish LFS data, $2^{\text {nd }}$ quarters of 2007-2010.

Differences are more clear in case of wage comparison between Poles in the UK and natives. In this case, distribution of native wages is unequivocally right skewed while wages of Polish migrants are, generally, lower and concentrated in the bottom of the wage distribution. Both comparisons suffer from obvious self-selection (as suggested above). Thus, in following section we will refer to PSM in order to address this particular issue.

\section{Results}

In this section we present and discuss results of a number of estimations addressing position of Polish well educated migrants in the UK. Following the identification strategy as described in previous section, we start with an attempt to eliminate the selection bias resulting from significant differences between groups of movers and stayers. Then we compare income position of Polish migrants in the UK with their "statistical twins" in Poland obtained through propensity score matching. Lastly, we assess the returns to education on the British labor market.

\section{Matching quality}

From the previous section it follows that Polish migrants in the UK are significantly different then stayers in terms of socio-demographics. These differences imply self-selection bias undermining "traditional" estimation techniques. We refer to propensity score matching as appropriate methodology in such a case. As discussed in the previous section migrants are matched to stayers based on gender, age (in years), education (in years), marital status and tenure with additional interactions of all variables added to obtain the adequate matching. The main aim is to obtain a set of "statistical twins" and to avoid the self-selection bias. Table 4 comprises the outcomes of the matching procedure, specifically before and after t-tests. 
Table 4. Matching quality

\begin{tabular}{|c|c|c|c|c|c|c|}
\hline Variable & $\begin{array}{l}\text { Poles in } \\
\text { the UK }\end{array}$ & $\begin{array}{l}\text { Poles in } \\
\text { Poland }\end{array}$ & $\begin{array}{c}\text { Poles in Poland } \\
\text { after PSM }\end{array}$ & $\begin{array}{c}\text { T-test } \\
\text { (before) }\end{array}$ & $\begin{array}{l}\text { T-test } \\
\text { (after) }\end{array}$ & $\begin{array}{c}\text { Bias } \\
\text { reduced }\end{array}$ \\
\hline & \multicolumn{6}{|c|}{ Total sample } \\
\hline Age & 31.08 & 39.98 & 31.43 & 0.00 & 0.40 & 91.40 \\
\hline Gender (female $=1$ ) & 0.47 & 0.47 & 0.51 & 0.99 & 0.00 & - \\
\hline Short tenure & 0.79 & 0.09 & 0.77 & 0.00 & 0.26 & 97.90 \\
\hline \multirow[t]{2}{*}{ Fulltime $\mathrm{x}$ short tenure } & 0.14 & 4.63 & 0.19 & 0.00 & 0.00 & 83.80 \\
\hline & \multicolumn{6}{|c|}{ With tertiary education } \\
\hline Age & 31.09 & 37.96 & 31.48 & 0.00 & 0.40 & 95.10 \\
\hline Gender (female $=1$ ) & 0.55 & 0.62 & 0.62 & 0.00 & 0.12 & 40.10 \\
\hline Short tenure & 0.78 & 0.05 & 0.77 & 0.00 & 1.00 & 100.00 \\
\hline Fulltime $\mathrm{x}$ short tenure & 0.45 & 0.03 & 0.37 & 0.00 & 0.09 & 88.70 \\
\hline
\end{tabular}

Source: UK LFS and Polish LFS data, $2^{\text {nd }}$ quarters of 2007-2010.

Based on the above presented data balancing properties after the matching are satisfactory. Differences with regard to (almost) all characteristics are clearly identifiable before the matching procedure ( $\mathrm{t}$-test before). Table 4 shows that the matching procedure was successful both in terms of statistically significant differences (t-test after) and bias reduction. Same conclusions hold true in case of the well educated (lower part of the table).

\section{Results and discussion}

Having eliminated the self-selection bias we provide a comparison of wages earned by Poles in the UK (movers) and Poles in Poland (stayers). Results of this comparison are presented below (for all migrants).

Table 5. PSM results: all Poles in the UK LFS, Poles in the Polish LFS as a control group

\begin{tabular}{l|cccccc}
\hline \hline Variable & $\begin{array}{c}\text { Poles in } \\
\text { UK }\end{array}$ & $\begin{array}{c}\text { Poles in } \\
\text { PL }\end{array}$ & $\begin{array}{c}\text { Poles in PL } \\
\text { matched }\end{array}$ & $\begin{array}{c}\text { T-test before } \\
\text { matching }\end{array}$ & $\begin{array}{c}\text { T-test after } \\
\text { matching }\end{array}$ & $\begin{array}{c}\text { N (UK LFS / PL } \\
\text { LFS) }\end{array}$ \\
\hline Hourly wage & 33.79 & 34.83 & 29.77 & $-1.97^{*}$ & $6.75^{* * *}$ & $1962 / 36408$ \\
Percentile & 28.19 & 51.3 & 42.0 & $-35.64^{* * *}$ & $-18.61^{* * *}$ & $1962 / 36408$ \\
Wage / average & 0.821 & 0.999 & 0.853 & $-17.20^{* * *}$ & $-2.92^{* * *}$ & $1962 / 36408$ \\
Wage / median & 0.904 & 1.07 & 0.915 & $-13.88^{* * *}$ & -0.87 & $1962 / 36408$ \\
Wage / median* & 1.06 & 1.07 & 0.915 & -0.99 & $10.90^{* * *}$ & $1962 / 36408$ \\
\hline \hline
\end{tabular}

* Nationality used for defining the reference group Source: UK LFS and Polish LFS data, $2^{\text {nd }}$ quarters of 20072010. Wages expressed in PLN (4PLN $\approx 1$ EUR). Wage conversion from GBP to PLN using the average annual exchange rate from YahooFinance.

If we refer to the full sample of Polish migrants in the UK, the raw data show that - on average their wages are lower than in the Polish LFS sample. As suggested above, this can be a pure statistical artifact only (due to self-selection) and for this reason propensity score matching was applied. Comparison with the matched sample ("statistical twins") reveals quite different picture and shows that Polish migrants in the UK are successful in that sense that they are able to earn more than their counterparts in Poland (on average). Notwithstanding, as suggested in the motivation section migration can be driven also by the sense of deprivation and thus it is useful to look at the relative side of wage comparison. 
In the relative sense migration means a significant worsening of the position in the income distribution, as clearly indicated by the percentile in Table 5 (28 versus 42 ). In previous section we claimed that people may compare themselves not to the whole population but rather more narrowly defined reference groups. We provide data on three such references groups. Comparison of relative earnings (wage/average and wage/median) provides similar conclusion: there is an increase in the relative deprivation as compared to stayers (but not as compared to the situation of a given person prior to migration!). Interestingly, however, situation changes slightly when we refer to alternate concept of reference group and we claim that immigrants compare themselves not to their counterparts in Poland but rather to a reference groups build up from other migrants (wage/median*). In this case, relative position of migrants improves.

In case of the well educated migrants the picture is even more puzzling (Table 6). As compared to their "statistical twins" highly skilled Poles in the UK earn less than stayers in both absolute (here difference is negligible) and relative terms. The position in the wage distribution is clearly lower (34 versus 54). Reference to more narrowly defined reference groups may suggest increase in relative deprivation. The only positive comparison results from inclusion of nationality as a factor accounting for defining the reference category (wage/median*).

Table 6. PSM results: well educated Poles in the UK LFS, well educated Poles in the Polish LFS as a control group

\begin{tabular}{|c|c|c|c|c|c|c|}
\hline Variable & $\begin{array}{c}\text { Poles in } \\
\text { UK }\end{array}$ & $\begin{array}{c}\text { Poles in } \\
\text { PL }\end{array}$ & $\begin{array}{c}\text { Poles in PL } \\
\text { matched }\end{array}$ & T-test (before) & T-test (after) & $\begin{array}{c}\mathrm{N} \text { (UK LFS / PL } \\
\text { LFS) }\end{array}$ \\
\hline Hourly wage & 38.48 & 52.16 & 38.35 & $-10.06 * * *$ & 0.09 & 624 / 7620 \\
\hline Percentile & 33.94 & 71.80 & 53.62 & $-34.75^{* * *}$ & $-10.97^{* * *}$ & 625 / 7620 \\
\hline Wage / average & 0.795 & 0.996 & 0.806 & $-9.15 * * *$ & -0.41 & $626 / 7620$ \\
\hline Wage / median & 0.904 & 1.10 & 0.889 & $-7.73 * * *$ & 0.37 & 627 / 7620 \\
\hline Wage / median* & 1.05 & 1.11 & 0.890 & $-1.75^{*}$ & $4.37 * * *$ & $628 / 7620$ \\
\hline
\end{tabular}

* Nationality used for defining the reference group

Source: UK LFS and Polish LFS data, $2^{\text {nd }}$ quarters of 2007-2010. Wages expressed in PLN (4PLN $\approx 1$ EUR).

Wage conversion from GBP to PLN using the average annual exchange rate from YahooFinance.

From the above presented results it follows that when controlling for self-selection bias Polish migrants in the UK (both the full sample and well skilled) are able to slightly improve their wages in absolute terms but are worse off in relative terms. These results are striking because they may question the very logic of labor migration. We suggest a number of explanations for this. First, in case of the recent Polish migration to the UK we refer to a very specific form of migration - temporary or circular one. In such a case relatively small increase in earning can be compensated by large savings in terms of daily spending. Thus, finally the income position of migrants can improve significantly. Second, we refer to relatively recent phenomena and it is well acknowledged that immigrants need time to be fully absorbed by the labor market in host country (and also to earn higher wages) - this is clearly reflected in the cohort effect as discussed above. Third, idea and practical meaning of reference groups used can be discussed and tested empirically. Last but not least, immigrants can face barriers to discount their human capital. This issue will be discussed extensively below.

Following the second identification strategy as discussed above we perform a modeling exercise to assess the elastiticity of wage versus education on the British labor market. Results of the 
number of estimations are presented below (in all cases tobit models with $\ln$ (wage) as dependent variable).

Table 7. Elasticity of wage vs. education on the UK labor market

\begin{tabular}{|c|c|c|c|c|c|c|}
\hline $\begin{array}{l}\text { Variable / } \\
\text { measure }\end{array}$ & (1) & (2) & $\begin{array}{l}\text { Full sample } \\
\text { (3) }\end{array}$ & (4) & (5) & $\begin{array}{c}\text { M } 25-45 \\
(6)\end{array}$ \\
\hline Age & $0.06^{*}$ & $0.06^{*}$ & $0.04^{*}$ & $0.05^{*}$ & $0.05^{*}$ & $0.09^{*}$ \\
\hline $\mathrm{Age}^{2}$ & $-0.001^{*}$ & $-0.0016^{*}$ & $-0.001^{*}$ & $-0.001^{*}$ & $-0.001^{*}$ & $-0.001 *$ \\
\hline Gender & $-0.14^{*}$ & $-0.14^{*}$ & $-0.12^{*}$ & $-0.12^{*}$ & $-0.12^{*}$ & \\
\hline Fulltime job & $0.19 *$ & $0.19 *$ & $0.08^{*}$ & $0.08^{*}$ & $0.08^{*}$ & $0.23^{*}$ \\
\hline Job tenure & $-0.05^{*}$ & $-0.04^{*}$ & $-0.03 *$ & $-0.03^{*}$ & $-0.03^{*}$ & $-0.01^{* *}$ \\
\hline Experience & $0.01^{*}$ & $0.01^{*}$ & $0.01^{*}$ & $0.01^{*}$ & $0.01^{*}$ & $0.01^{*}$ \\
\hline Industry & & Yes* & Yes* & Yes* & Yes* & Yes* \\
\hline Occupation & & & Yes* & Yes* & Yes* & Yes* \\
\hline Primary edu & $-0.20^{*}$ & $-0.20^{*}$ & $-0.09 *$ & $-0.09 *$ & $-0.09^{*}$ & $-0.09 *$ \\
\hline Tertiary edu & $0.43^{*}$ & $0.43^{*}$ & $0.22^{*}$ & $0.23^{*}$ & $0.23^{*}$ & $0.22^{*}$ \\
\hline Tertiary x A8 & & & & $-0.23 *$ & $-0.17^{*}$ & $-0.11^{* *}$ \\
\hline Tertiary x PL & & & & & $-0.07^{* *}$ & $-0.16^{*}$ \\
\hline Constant & $0.83^{*}$ & $0.53^{*}$ & $0.75^{*}$ & $0.75^{*}$ & $0.75^{*}$ & $-0.24^{*}$ \\
\hline$\sigma$ & $0.49^{*}$ & $0.49^{*}$ & $0.43^{*}$ & $0.43^{*}$ & $0.43^{*}$ & $0.45^{*}$ \\
\hline $\mathrm{N}$ & 201,935 & 201,770 & 201,739 & 201,739 & 201,739 & 46,618 \\
\hline
\end{tabular}

Source: Source: UK LFS data, $2^{\text {nd }}$ quarters of 2007-2010.

The main aim of the estimation was to assess the return to education on the British labor market (in general terms and for A8 immigrants specifically). Thus, set of the models is estimated to control for particular sets of covariates (all signs are as expected and predicted by theoretical considerations). Model (1) represents a classical version of Mincerian equation and points to a significant wage premium for human capital (tertiary education). This outcome does not change when controlling for sector of employment (model (2)) and occupation (model (3)). Notwithstanding, in the latter model the wage premium for tertiary education is lower. Models (4) and (5) include additionally interaction terms to estimate the value of $\lambda_{1}$ and $\lambda_{2}$ (as suggested in previous section). Both variables are to be interpreted in terms of "special treatment" of immigrants (and immigrants from Poland particularly) when controlling for set of traditional variables. From model (4) it follows that A8 immigrants are not able to reach the wage premium for tertiary education (or the wage premium is negligible only). Model (5) addresses the situation of well educated Polish migrants on the British labor market and it implies that their situation is even worse than in case of A8 immigrants - they suffer (statistically significant) wage penalty.

Similarly to previous analysis, also in this case self-selection bias is an issue. In this case, however, we apply alternate identification strategy and peform the robustness check while running the model (5) only for males at mobile age (25-45). In that way we are able to avoid most of the problems resulting from structural differences between analyzed populations. Results of model (6) show, however, that outcomes do not change significantly (or the wage penalty is even larger).

There are several explanations for the (very) poor performance of well educated Poles on the UK labor market. First, cohort effect can be an issue and thus more in-depth analysis would be 
advisable to control for dynamics of the labor market integration. Second, comparison with other A8 immigrants points to the hypothetical importance of 'crowding' effect. It is well possible that due to the massive scale of inflow from Poland the level of concentration in particular labor market niches in case of Polish migrants is much higher than observed in case of other newcomers from the CEE. Third, low returns to education as observed for Polish well educated migrants can be interpreted in terms of low ability to transfer their skills. To verify this proposition an inclusion of the language proficiency as an additional control variable would be necessary (which was not possible due to data deficiencies).

\section{Conclusions}

Results presented in last section shed some new light on the recent migration from Poland to the UK. Comparison of Polish migrants and their "statistical twins" in Poland (stayers) reveals that change in wage rate is relatively small or even negligible for highly educated movers. Moreover, for large part of the well educated migrants mobility might have led to relative deprivation in income terms. Our results suggest that ethnic niches or migrant networks can provide a solution to avoid it through creation of new reference categories. Last but not least, Polish education is difficult to be discounted on the British labor market. Polish well educated migrants are commonly employed far below their skills and even in purely pecuniary terms suffer (on average) wage penalty.

When saying all this we do not claim that the recent wave of Polish migrants - in quantitative terms one of the most important migration processes in contemporary Europe - behave in an irrational way. Rather we suggest that the importance of both absolute as well as relative wage argument does not seem to be the main driver of this particular migration flow. First of all, we argue that decision to migrate may be conditional on the opportunities posed by the labor markets in sending and receiving country which are hardly quantifiable. In our case those Polish migrants who suffer wage penalty in the UK still have a job which could be not necessarily the case on domestic labor market. Furthermore, also social and cultural aspects may play an important role. Generally, we argue that decisions to migrate are far more complex than foreseen by neoclassical economic migration theories.

Research presented constitutes only a first step towards a better understanding of causes and impacts of recent Polish migration. Future research should more closely assess such issues as: process of labor market incorporation of Polish migrants (including changes in wage and income position), transferability of skills (with inescapable inclusion of language variables), and business cycle effects (particularly important at the time of Europe wide crisis). 


\section{References}

Ackers, Louis \& Bryony Gill. 2008. Moving People and Knowledge: Scientific Mobility in an Enlarging European Union. London: Edward Elgar Publishing.

Adda, Jerome, Dustman, Christian \& Joseph-Simon Görlach. 2014. Migrant Wages, Human Capital Accumulation and Return Migration. Manuscript.

Barrett, Alan. 2009. EU Enlargement and Ireland's Labour Market. IZA Discussion Papers 4260, Institute for the Study of Labor (IZA).

Alan Barrett \& Yvonne McCarthy. 2007. Immigrants in a Booming Economy: Analysing Their Earnings and Welfare Dependence. LABOUR 21(4-5): 789-808.

Barrett, Alan \& FitzGerald, John \& Brian Nolan. 2002. Earnings inequality, returns to education and immigration into Ireland. Labour Economics 9(5): 665-680.

Borjas, George. 1985. Assimilation, Cohort Quality and the Earnings of Immigrants. Journal of Labour Economics 3(4): 463-489.

Borjas, George J. 1987. Self-selection and the earnings of immigrants. American Economic Review 77: 531-553.

Borjas, George J. 1994. The Economics of Immigration. Journal of Economic Literature 32: 1667-1717.

Caliendo, Marco and Sabine Kopeinig. 2008. Some Practical Guidance for the Implementation of Propensity Score Matching. Journal of Economic Surveys 22(1): 31-72.

Card, David, Dustmann, Christian and Ian Preston. 2012. Immigration, Wages, And Compositional Amenities. Journal of the European Economic Association, European Economic Association 10(1): 78-119.

Carletto, Gino, Davis, Ben, M. Stampini, S. Trento and A. Zezza. 2004. Internal Mobility and International Migration. ESA Working Paper 04-13, FAO: Rome.

Chiswick, Barry. 1978. The Effect of Americanisation on the Earnings of Immigrant Men. Journal of Political Economy 86: 897-921.

Chiswick, Barry and Miller Paul W. 2002. Immigrant Earnings: Language Skills, Linguistic Concentrations and the Business Cycle. Journal of Population Economics 15(1): 31-57.

Chiswick, Barry and Miller Paul W. 1995. The Endogeneity between Language and Earnings: International Analyses. Journal of Labor Economics 13(2): 246-188.

Clark, Ken and Stephen Drinkwater. 2008. The labour-market performance of recent migrants. Oxford Review of Economic Policy 24(3): 495-516.

Clark, Ken and Stephen Drinkwater. 2009. The Labour Market Impact of Recent Immigration on Ethnic Groups in The UK. Nordic Journal of Political Economy 35(4): 1-24.

Csedo, Krisztina. 2008. Negotiating Skills in the Global City: Hungarian and Romanian Professionals and Graduates in London. Journal of Ethnic and Migration Studies 34(5): 802-823.

Czaika, Mathias. 2011. Internal and international migration as response of double deprivation: some evidence from India, Proceedings of the German Development Economics Conference, Berlin 2011, No. 21

Drinkwater, Stephen, Eade, James and Michal Garapich. 2009. Poles Apart? EU Enlargement and the Labour Market Outcomes of Immigrants in the UK. International Migration 47: 161-90.

Dustmann, Christian, Frattini, Tommaso and Caroline Halls. 2010. Assessing the Fiscal Costs and Benefits of A8 Migration to the UK. Fiscal Studies 31(1): 1-41. 
Dustmann, Christian and Francesca Fabbri. 2003. Language Proficiency and the Labour Market Performance of Immigrants in the UK. Economic Journal 113(489): 695-717.

Dustmann, Christian, Glitz, Albrecht and Thorsten Vogel. 2010. Employment, wages, and the economic cycle: Differences between immigrants and natives. European Economic Review 54(1): 1-17.

Dustmann, Christian, Frattini, Tommaso and Ian P. Preston. 2013. The Effect of Immigration along the Distribution of Wages. Review of Economic Studies 80(1): 145-173.

Dustmann, Christian. 2000. Temporary Migration and Economic Assimilation. IZA Discussion Paper 186.

Fischer, Peter, Martin, Rainer and Thomas Straubhaar. 1997. Should I Stay or Should I Go?, in: Hammar, Tomas, Brochmann, Grete, Tamas, Kristof and Thomas Faist (eds.) International Migration, Immobility and Development. Multidisciplinary Perspectives. Oxford / New York: Berg, pp. 49-90.

Grabowska, Izabela and Marek Okolski. 2009. Migracja ostatnia? Warsaw: Scholar.

GUS. 2014. Informacja o rozmiarach i kierunkach emigracji z Polski w latach 2004-2013 (notatka informacyjna). Warsaw: GUS.

Hansen, Jorgen and Magnus Lofstrom. 2003. Immigrant Assimilation and Welfare Participation: Do Immigrants Assimilate Into or Out of Welfare? The Journal of Human Resources 38(1): 74-98.

Harris, John R. and Michael P. Todaro. 1970. Migration, Unemployment, and Development: A Two-Sector Analysis. American Economic Review 60: 126-42.

Hatton, Timothy J. Jeffrey G. Williamson, Jeffrey. 2002. What Fundamentals Drive World Migration? CEPR Discussion Papers 3559.

Heckman, James J., Ichimura, Hidehiko and Petra Todd. 1998. Matching As An Econometric Evaluation Estimator. Review of Economic Studies 65: 261-294.

Jaźwińska, Ewa and Marek Okólski (Eds). 2001. Ludzie na huśtawce. Migracje między peryferiami Polski i Zachodu. Warsaw: Scholar.

Kaczmarczyk, Pawel. 2005. Migracje zarobkowe Polaków w dobie przemian. Warsaw: Wydawnictwa Uniwersytetu Warszawskiego.

Kaczmarczyk, Pawel. 2011. Polen in Bewegung - Migration nach dem EU-Beitritt. Osteuropa 61(2011): 175-188.

Kaczmarczyk, Pawel. 2013. Central and Eastern European migration, post-World War II to present. In: Ness, Emmanuel (Ed.) The Encyclopedia of Global Human Migration. New York: Wiley.

Kaczmarczyk, Pawel and Marek Okólski. 2008. Demographic and economic impacts of Migration on Poland. Oxford Review of Economic Policy 24(3), 600-625.

McDonald James T. and Christopher Worswick. 1998. The Earnings of Immigrant Men in Canada: Job Tenure, Cohort and Macroeconomic Conditions. Industrial and Labor Relations Review 51(3): 465-482.

Mundell, Robert. 1957. International Trade and Factor Mobility. American Economic Review 47(3): 321335.

OECD. 2007. International Migration Outlook 2007. Paris: OECD.

Okólski, Marek \& John Salt. 2014. Polish emigration to the UK after 2014: Why did so many come? Central and Eastern European Migration Review 3(2): 11-37.Özden, Caglar. 2006. Educated Migrants: Is There Brain Waste?. In: Özden, Caglar and Maurice Schiff (eds). International Migration, Remittances and the Brain Drain. Washington: The World Bank and Palgrave Macmillan.

Piore, Michael. 1980. Birds of Passage: Migrant Labor and Industrial Societies. Cambridge: Cambrdige University Press. 
Portes, Alejandro and Robert L. Bach. 1980. Immigrant Earnings: Determinants of Economic Attainment among Cuban and Mexican Immigrants in the United States. International Migration Review 14: 315-341.

Quinn, Michael. 2006. Relative deprivation, wage differentials and Mexican migration. Review of Development Economics 10: 135-53.

Rivera-Batiz, Francisco L. 2007. How Do Migrants from Latin America and the Caribbean Fare in the US Labour Market? The World Economy 30(9): 1399-1429.

Rivera-Batiz, F. L. 1990. English language proficiency and the economic progress of immigrants. Economic Letters: 34: 295-300.

Rosenbaum, Paul R. and Donald B. Rubin. 1983. The Central Role of the Propensity Score in Observational Studies for Causal Effects. Biometrika 70(1): 41-55.

Samuelson, Paul. 1948. International Trade and the Equalisation of Factor Prices, Economic Journal 58: 163-184.

Shields, Michael A. and Stephen Wheatley Price, S. 2002. The English language fluency and occupational success of ethnic minority immigrant men living in English metropolitan areas. Journal of Population Economics: 15: 137-136.

Shields, Michael A. and Stephen Wheatley Price, S. 1998. The Earnings of Male Immigrants in England: Evidence from the Quarterly LFS. Applied Economics 30: 1157-1168.

Sjaastad, Larry A. 1962. The Costs and Returns of Human Migration. The Journal of Political Economy 70(5): 80-93.

Stark, Oded and Simon Fan. 2011. Why would some migrants choose to engage in degrading work? Discussion Papers 101648, University of Bonn, Center for Development Research (ZEF).

Stark, Oded and Wang You Qiang. 2000. A Theory of Migration as a Response to Relative Deprivation. German Economic Review 1(2): 131-143.

Stark, Oded Nancy H. Chau. 1998. Human Capital Formation, Asymmetric Information, and the Dynamics of International Migration. Economics Series 52, Institute for Advanced Studies.

Stark, Oded and Edward J. Taylor. 1991a. Relative deprivation and migration : theory, evidence, and policy implications. Policy Research Working Paper Series 656, The World Bank.

Stark, Oded and Edward J. Taylor. 1991b. Migration Incentives, Migration Types: The Role of Relative Deprivation. Economic Journal 101(408): 1163-78.

Stark, Oded and Edward J. Taylor. 1989. Relative deprivation and international migration. Demography 26(1): 1-14.

Stark, Oded and Yitzhaki, Shlomo. 1988. Labour Migration as a Response to Relative Deprivation. Journal of Population Economics 1.

Stark, Oded and David E. Bloom. 1985. The New Economics of Labor Migration. American Economic Review 75(2): 173-178.

Stark, Oded. 1984. Rural to Urban Migration in LDCs: A Relative Deprivation Approach. Economic Development and Cultural Change 32: 475-86.

Stola, Dariusz. 2010. Kraj bez wyjścia? Warsaw: IPN.

Strzelecki, Paweł and Wyszynski, Robert. 2011. Potential implications of labour market opening in Germany and Austria on emigration from Poland. MPRA Paper 32586, University Library of Munich, Germany. 
UNDP. 2009. Overcoming barriers: Human mobility and development. Human Development Report 2009. New York: UNDP.

Won, Fy Lee. 2012. The Effect of Relative Income in the Dynamics of Migration: Evidence from the VHLSS Panel Data. University of Minnesota (unpublished thesis).

http://ageconsearch.umn.edu/bitstream/142096/2/Won PlanB Paper FINAL.pdf 